\title{
Taxation of the Digital Economy
}

\section{Krister Andersson ${ }^{*}$}

With the growth of the digital economy the issue of taxation of corporations based on the market where they sell their products and services has gained renewed interest. The Estonian EU Presidency has digital issues high on its agenda, including taxation. The work is expected to provide input to the ongoing OECD agenda on taxation of the digital economy. Action point one in the Base Erosion and Profit Shifting (BEPS) project concerned this issue but no consensus was reached. ${ }^{1}$ The EU Commission also initiated work on the digital economy and an expert group issued a report in $2014 .^{2}$ One of the conclusions was that digitalization affects all businesses and special rules for the digital economy were considered unwarranted and probably not possible without creating substantial distortions.

Currently, much work is underway on the taxation of the digital economy. The European Economic and Social Committee (EESC) has been asked by the EU Presidency to write an opinion before the end of 2017 on the taxation of the collaborative economy to feed into the discussions in the EU Council. The OECD together with Business and Industry Advisory Committee to the OECD (BIAC) is trying to identify business models used in the digital economy. At the March 2017 G20 finance ministers' meeting in Baden-Baden, the OECD was asked to deliver an interim report on the challenges of the digital economy by April 2018, followed by a final report in $2020 .^{3}$

One avenue for taxing the digital economy is to define virtual permanent establishments (PE). The Estonian
Presidency has initiated discussions in the Council with the aim of working toward such a definition and providing input into the OECD process. The need to change the OECD Transfer Pricing Guidelines regarding PE is recognized. The changes following Action point 7 on PE and Action Points 8-10 on Intangibles are considered to not adequately address taxation of digital platforms and businesses providing goods and services in countries without, or with limited, PE presence.

The European Parliament has in its draft report on the Council directive on a Common Consolidated Corporate Tax Base (CCCTB) expressed that 'Taking into account the digital change in the business environment, it is necessary to ensure that companies which generate revenues in a Member State without having a physical establishment but digital presence in that Member State should be treated in the same way as companies having a physical establishment.' 4

Large US businesses like Apple, Google and Microsoft have attracted a lot of attention in the corporate tax debate during recent years. The idea of making the corporate tax destination based in one way or another has been raised. At the same time, the new administration in the US has been discussing the possibility of imposing another form of destination based corporate tax, in which export earnings would be tax exempt and imports not deductible for calculation of the US corporate profit tax.

Even a partial adjustment of the application of taxation principles would have large implications for investments, jobs and corporate tax revenues in individual countries.

\section{Notes}

Member, European Economic and Social Committee, and Chairman, Tax Policy Group, BusinessEurope. Views expressed are personal. Email: Krister.Andersson@eesc. europa.eu

OECD, BEPS 2015 Final reports, http://www.oecd.org/tax/beps-2015-final-reports.htm (accessed 10 Sept. 2017).

Expert Group on Taxation of the Digital Economy, http://ec.europa.eu/taxation_customs/business/company-tax/tax-good-governance/expert-group-taxation-digital-econ omy_en (accessed 10 Sept. 2017).

www.oecd.org/ctp/beps/major-progress-reported-towards-a-fairer-and-more-effective-international-tax-system.htm, http://taxinsights.ey.com/archive/archive-news/oecdshares-updates-on-tax-activities-in-26-june-2017-tax-talk-webcast.aspx (accessed 10 Sept. 2017).

4 2016/0336(CNS) Committee on Economic and Monetary Affairs, European Parliament, Rapporteur: Alain Lamassoure (13 July 2017), http://www.europarl.europa.eu/sides/ getDoc.do? type $=$ COMPARL\&reference $=$ PE-608.035\&format $=$ PDF\&language $=$ EN\&secondRef $=01$ (accessed 10 Sept. 2017). 'Moreover, existing corporate tax systems reflect economic realities of the last century where businesses were clearly linked to a local market. Globalisation, digitalisation of the world economy, e-commerce and new business models offer significant opportunities for businesses as well as for European citizens. However, they also represent challenges with regard to prevention of market distortion, tackling tax avoidance and tax evasion. Businesses active in the EU without a physical establishment have to be treated in the same way as businesses having a physical establishment in the EU. Modern tax systems of the 21 st century must address specificities of the new globalised digital economy and this is why your rapporteur believes that the СССТВ should also encompass the concept of a digital presence and the capture of the commercial value of personal data. 


\section{TAXation of Sales}

The traditional way in the EU to tax consumption is through sales taxes or VAT/GST taxes. The VAT system in the EU is currently designed on a destination basis and consumption is taxed in the country of the consumer. Corporate profit taxes have in principal remained based on profits and the allocation of taxation rights has not been based on sales. Formulary apportionment of state corporate taxes is however used in the US and is proposed to be implemented in the EU through the CCCTB. The apportionment formula for the CCCTB applies sales as one factor out of three (labour, capital and sales). National corporate tax rules have, with the exception of some anti-tax avoidance measures, not taken sales into account for corporate tax obligations.

Profits and taxes are assessed and levied where real economic activity takes place and value is created. Value creation is defined according to rules agreed in the BEPS project, as reflected in the Transfer Pricing Guidelines. Headquarters, control, capacity to finance and bear risks, IP-rights etc. are considered important revenue raisers and indicative of taxation obligations. Sales of course generate profits but taxation rights have been geared to assess Arm's Length Pricing between entities and to allocate profits between companies and countries. A destination based corporate profit tax may not, and most likely would not, correspond to taxation where value is created.

If a corporation has no PE in a country and sells only through electronic means from a remote server, no corporate profit tax is due in the country of sale. This has irritated among others the French, who have argued that they should have part of the corporate profit tax generated in such a situation. ${ }^{5}$ Other countries have not been keen on handing over some of their tax revenues if another country's claim is only based on sales.

Sales of goods and services have generally been subject to VAT and to the extent new platforms create value added, VAT would be due. It is somewhat unclear if this principle has been upheld to its full extent. It may not be obvious to what extent and where value has been added. The destination principle has however clearly attributed VAT revenue to the country where consumption is deemed to take place.

\section{How to DiVIDE THE PIE}

The division of tax revenues among countries is at the heart of this matter. If a virtual PE could be established, countries with large markets would be able to tax a part of the total corporate profit even if no physical PE exists in the country of sales. Such a change would have not only revenue implications but may change tax competition in the world.

Smaller countries have been successful in making investment opportunities economically viable and in attracting investments and businesses by lowering their corporate tax rate. Even if PEs had to be established in larger countries, a large part of the overall profit would be attributed to the low tax country, in line with the Transfer Pricing Guidelines.

If virtual PEs are defined, a part of the overall profit would be allocated to and taxed in larger countries where sales take place. Since larger economies tend to have higher statutory corporate tax rates, the effective level of corporate tax would increase. This will of course have implications for overall investment and job creation. The OECD assessed in 2010 that the corporate tax is the most harmful tax for economic growth. ${ }^{6}$

Since corporate taxation would be partly levied in the country where sales take place, possibilities for smaller countries to attract investments and create jobs by imposing a low corporate tax rate would be reduced. Lowering the corporate tax rate would be a less effective instrument for making investments economically viable or impacting where production takes place since the level of corporate tax would not be as closely linked to the country of production. Instead, labour cost and the cost of energy and resources will become relatively more important. This may lead to a downward pressure on wages, which may only partially be offset by a reduction of taxes on wages and salaries. Wage earners in countries with high labour costs may face increased downward pressure when the corporate tax rate becomes a less effective instrument to boost the competitiveness of a country. In general, taxation power of nations will move from small to large countries. There might also be an effect that large countries may find it tempting to reduce their corporate tax rate, in order to induce more sales in the country and thereby increase corporate (and consumption) tax revenues. Corporate tax rates would then tend to converge, as smaller countries will be less inclined to reduce rates while larger economies may have incentives to lower their rates.

\section{Notes}

In a recent court case, Google was found not liable to French taxation claims, 12 July 2017. Google employs 700 people in France through its subsidiary there, but the company used a division based in Ireland to sell French customers digital services such as its well-known advertising platform AdWords, according to court filings. The case focused on whether Google owed taxes in France, even though it sold services from Ireland. French tax authorities argued that Google's French employees helped to sell the ad space, even if the final contracts were signed with the Irish subsidiary. In its rulings on 12 July 2017, the court agreed with Google. It found that the Irish unit did not have a 'stable' presence in France, meaning that the French tax authorities could not collect corporate income and withholding taxes from it. The court also decided that other taxes, including a value-added tax, did not apply. See https://mobile.nytimes.com/2017/07/12/business/13google.html? (accessed 10 Sept. 2017).

6 OECD, 2010, Tax Policy Reform and Economic Growth. Ch. 1 of this report investigates how tax structures could best be designed to support GDP per capita growth. The analysis suggests a tax and economic growth ranking order according to which corporate taxes are the most harmful type of tax for economic growth, followed by personal income taxes and then consumption taxes, with recurrent taxes on immovable property being the least harmful tax. 
Countries with a trade and current account deficit will collect more of the corporate tax revenues. This may serve as a disincentive to restore macro-economic stability. Furthermore, the procyclicality of public finances may increase. Countries which promote excessive spending would be rewarded with higher corporate tax revenues while countries consolidating their public finances would collect less. Today, export-oriented economies, like the Swedish or German economy, collect the tax revenue despite sales being outside their territory. This will change if virtual PEs are introduced and taxation is based on sales. Small countries with a strong export sector would be hurt more than other ones.

The rules of virtual PEs would not only apply to digital businesses, like Google and Apple, but to all businesses. Ring fencing is not possible, nor desirable. It means that it is not a question of creating a level playing field between 'old' and 'new' businesses. The tax burden will be different for all businesses and tax collection for all countries will be affected.

An Estonian company selling T-shirts over the internet will no longer only be taxed in Estonia for its profits, unless it is a purely domestic oriented company. There would be no tax benefit for the company to locate its business in Estonia if sales are truly global since the corporate tax burden would be based on the destination of sales, at least to a very large extent. If thresholds are introduced for taking sales into account, distortions between firms of different sizes would be introduced, potentially creating obstacles for expansion as well as cross-border sales.

Countries like India, China and Brazil have for a long time argued that taxes should be paid where sales take place. The controversy of taxation according to source or residence principle goes back to the early 1920s. The International Chamber of Commerce (ICC) argued in favour of source taxation while the League of Nations decided to opt for residence based taxation. ${ }^{7}$ Many developing countries have continued to argue in favour of a reversal of the decision to use the residence principle. For the Brazil, Russia, India, China (BRIC) countries, a redefined PE definition would entail even more tax revenues than the changes obtained in the BEPS project. So far these countries have mainly argued that operating on their markets entails risks (and therefore high profitability) and the value of the IP is maintained and developed due to the presence in their markets and therefore a larger part of global profits than reflected in sales, should be taxable in their country. With a virtual PE, their line of argumentation would be simplified and strengthened. Substantial revenues might well be transferred from the EU countries to the BRIC countries.

\section{Sales or profit tax?}

The principal question is however whether the corporate profit tax should be transformed into a destination, salesbased tax. It is a form of formulary apportionment requiring global acceptance and uniform implementation in order to avoid international double taxation. The US proposal for a destination based corporate profit tax is in many ways the opposite of the virtual PE concept. There, export would be exempt, while in the European context, export would be the very basis for taxation. If the US should go ahead with its border adjusted destination based tax, US companies may be exempt on profits made on export earnings, while the US would be allowed to tax the profits on sales European businesses make in the US (European businesses would have virtual PEs in the US). It is questionable whether the US would silently accept its businesses being taxed on sales in Europe. If they are, US corporate tax revenues would, under present US rules, be reduced since foreign tax credit would increase when profits are repatriated and US companies have paid taxes on profits allocated to European virtual PEs. The US rules on Foreign Tax Credit would however likely be changed if a border adjusted corporate tax is introduced.

The virtual PE issue addressed by the Estonian Presidency is a courageous project. It has broad implications for all businesses and all countries. Moreover, both international trade and domestic economic policy will be affected. Therefore, it requires a thorough analysis of tax principles and of how tax revenues will be affected. The introduction of virtual PEs in international corporate taxation will affect the allocation of tax revenues between small and large countries as well as the allocation of tax revenues among European, US and BRIC countries. The total effect on revenue may be large, since the same country will collect not only destination based consumption taxes but also a substantial share of the corporate taxes. Even with a piecemeal approach, with only a partial reallocation of taxation rights to countries where sales take place, unanimity and agreement at the OECD/G20 level is necessary. Realistically, implementation and interpretation would however still be diverse, resulting in an increase in disputes and in double taxation cases. The agreed EU Directive on Dispute Resolution Mechanisms is in this respect very important but it may need to be strengthened further and it must be followed up at the OECD/G20 level.

\section{Notes}

See Brett Wells \& Cym H. Lowell, Income Tax Treaty Policy in the 21st Century: Residence vs. Source, 5(1) Colum. J. Tax L., https://taxlawjournal.columbia.edu/article/incometax-treaty-policy (accessed 10 Sept. 2017). 